\title{
Genetic regulation of parasite infection: empirical evidence of the functional significance of an IL4 gene SNP on nematode infections in wild primates
}

\author{
Dagmar Clough ${ }^{1,2^{*}}$, Peter M Kappeler ${ }^{1,2}$ and Lutz Walter ${ }^{3}$
}

\begin{abstract}
Background: Susceptibility to parasite infection affects fitness-related processes, such as mate choice and survival, yet its genetic regulation remains poorly understood. Interleukin-4 (IL4) plays a central role in the humoral immune defence against nematode parasite infections, inducing IgE switch and regulation of worm expulsion from the intestines. The evolutionary and functional significance of single nucleotide polymorphisms (SNPS) in IL4-genes is known, yet empirical information on the effect of IL4 SNPs on gastro-intestinal infections is lacking. Using samples from a population of wild red-fronted lemurs (Eulemur fulvus rufus, Primates: Lemuridae), from western Madagascar, we explored the association of IL4-gene promoter polymorphisms with nematode infections and investigated a possible functional role of the IL4 polymorphism on male reproductive success.

Results: Using sequence analyses of lemur DNA we detected a new SNP in the $I L 4$ gene promoter area. Carriers of the genotype $T / T$ showed higher nematode infection intensities than individuals of genotypes $C / T$ and $C / C$. Genetic population analyses using data from more than 10 years, suggested higher reproductive success of $T / T$ males than expected.

Conclusions: Our results suggest a regulatory effect of an $I L 4$ gene promoter polymorphism on the intensity of parasite infections in a natural population of red-fronted lemurs, with a seemingly disadvantageous genotype represented in low frequencies. Long-term population analyses, however, point in the direction of a negative frequency-dependent association, giving a fitness advantage to the rare genotype. Due to low frequencies of the genotype in question conclusive evidence of a functional role of IL4 polymorphism cannot be drawn here; still, we suggest the use of IL4 polymorphism as a new molecular tool for quick assessment of individual genetic constitution with regard to nematode infection intensities, contributing to a better understanding of the actual components of the immune response that mediate protection against gastro-intestinal parasites.
\end{abstract}

\section{Background}

Parasite infections impose high costs on both human and animal populations, increasing morbidity and mortality, particularly in hosts under ecological stress [1-3]. Understanding the genetic regulation of parasite resistance in natural population is of major importance for understanding host-parasite evolution and host sexual selection processes. In the past, great effort has been devoted to study major histocompatibility complex (MHC) diversity and compatibility as a key element of

\footnotetext{
* Correspondence: dclough@gwdg.de

'Behavioral Ecology and Sociobiology Unit, German Primate Center, Kellnerweg 4, 37077 Göttingen, Germany

Full list of author information is available at the end of the article
}

genetic regulation of parasite resistance and a potential driving force in sexual selection processes, respectively [4-12]: host genetic variation can be promoted by parasites through frequency-dependent selection on advantageous resistance alleles $[10,13]$, and individuals that are heterozygous at the MHC are expected to have a selection advantage and to be better capable of combating a variety of infectious agents than MHC homozygotes $[5,7,14]$. Additionally, some studies report correlations between parasite resistance and individual heterozygosity that are explained by reduced fitness values of homozygous individuals for traits that are controlled by directionally dominant loci $[13,15,16]$. Still, there is accumulating evidence that individual heterozygosity 
often appears to be a weak predictor of parasite infection and the importance of specific alleles of candidate genes in regulation of parasite infection has been suggested $[15,17]$. In this respect, cytokine genes such as interleukins are natural candidates due to their major regulatory role in helminth parasite susceptibility [18], and recently Fumagalli and colleagues [19] highlighted their evolutionary significance as a target of balancing selective processes.

Immunity to helminth parasite infections is mainly mediated by $\mathrm{CD} 4+\mathrm{T}$-helper 2- $\left(\mathrm{T}_{\mathrm{H}} 2\right)$ lymphocytes with promotion of $\mathrm{T}_{\mathrm{H}} 2$ immune responses (humoral immune responses) being dependent on the cytokine interleukin4 (IL-4) [18]. IL-4 not only induces and sustains $\mathrm{T}_{\mathrm{H}} 2$ responses and suppresses $\mathrm{T}_{\mathrm{H}} 1$ responses, but also initiates immunoglobulin (Ig) isotype switching to IgE, which plays an essential role in anti-parasite immunity [20]. Evidence mainly from human diseases is accumulating that single nucleotide polymorphisms (SNPs) in the promoter region of the interleukin 4 gene (IL4) affect its transcription, resulting in altered IL-4 protein levels and, hence, in either higher or lower IgE titres [21-24]. In this way, IL4 SNPs can effectively influence the intensity of various infections [22,25-30], including enteric pathogens [31-34]. Still, despite its key role in the regulation of parasite infections and resulting evolutionary significance of IL4 polymorphisms [19], empirical evidence of the importance of IL4 on the intensity of parasite infections in natural population is lacking.

This study integrates field parasitology and population genetics to investigate the functional significance of polymorphisms in the IL4 gene on gastro-intestinal infections in a wild non-human primate: the red-fronted lemur (Eulemur fulvus rufus).

Red-fronted lemurs live in small multi-male, multifemale groups of 5-12 individuals with an even or slightly male-biased adult sex ratio [35,36]. Reproduction is highly seasonal with only one mating period per year. During this three-to four-week period, females are in oestrus for approximately one day and mate promiscuously with several males $[37,38]$, resulting in a very low male mating skew within a group [39]. In contrast, reproductive skew is very high as male reproductive success is positively correlated with male dominance rank [40]. Variation in parasite infection of the red-fronted lemur population on which this study is based on has been investigated in detail and is known to differ significantly among individuals but not between males of different rank [41].

The specific objectives of our study were: (1) to identify promoter SNPs in the IL4 gene of the red-fronted lemur, (2) to associate both the respective IL4 SNP genotypes and a measure of individual heterozygosity with intensities of nematode infections, (3) to identify a possible functional role of the IL4 alleles in selective processes by exploring long-term fitness consequences between males of different genotype constitutions. We expected frequency-dependent selection to result in a higher frequency of genotypes, which provide the best resistance to parasites [10]. Further, if IL4 does obtain a functional role in selective processes, we predicted a fitness advantage of individuals with a beneficial IL4 genotype.

\section{Results}

IL4 promoter polymorphism in red-fronted lemurs

After sequencing a $528 \mathrm{bp}$ fragment of the IL4 promoter region of the red-fronted lemur, we identified a $\mathrm{C} / \mathrm{T}$ polymorphism at position -485 bp upstream of the transcription start site (Figure 1). The $-485 \mathrm{C} / \mathrm{T}$ was the only SNP found within this part of the promoter sequence. All possible genotypes $(\mathrm{C} / \mathrm{C}, \mathrm{C} / \mathrm{T}, \mathrm{T} / \mathrm{T})$ were present in the total lemur population studied between 1996 and 2007 ( $\mathrm{N}=64$ individuals) with the following frequencies: C/C: $51.6 \%(\mathrm{n}=33$ individuals), C/T: $37.5 \%$ $(\mathrm{n}=24), T / T: 10.9 \%(\mathrm{n}=7)$. In a subset of this dataset, which was used for combined parasitological and genetic analyses (see below; yr 2007, $\mathrm{n}=24$ individuals) frequency distribution was C/C: $50.0 \%(\mathrm{n}=12$ individuals), $\mathrm{C} / \mathrm{T}: 37.5 \%(\mathrm{n}=9), \mathrm{T} / \mathrm{T}: 12.5 \%(\mathrm{n}=3)$. Frequency distribution of genotypes did not deviate from a distribution expected under Hardy-Weinberg equilibrium (Fisher's exact test, $\mathrm{p}=0.86, \mathrm{df}=2$ ).

\section{Parasite infection intensities and association with IL4 gene promoter polymorphism}

During the study period in 2007, all lemurs of both sexes (13 males, 11 females) were parasitized by at least three helminth morpho-species [see Ref 42 for more details] with most prominent infections with the nematode species Lemuricola vauceli and Callistoura sp. Animals showed no signs of clinical significance during the period of the study that could be linked to acute parasite infections (intense behavioural observation were conducted on the same animals for other purposes, see Refs $[41,42])$. Intensities of individual nematode infections ranged from 0 to 3300 eggs per faecal sample with median infection intensity of 100 eggs/g faeces.

The intensity of nematode infections differed significantly between IL4 genotypes (Figure 2, Table 1): individuals of genotype $\mathrm{T} / \mathrm{T}$ had higher parasite egg outputs than individuals of the more frequent genotypes $\mathrm{C} / \mathrm{T}$ and $\mathrm{C} / \mathrm{C}\left(\mathrm{t}_{24,2}=2.20, \mathrm{p}_{\text {CС-TT }}=0.04, \mathrm{p}_{\text {СТ-TT }}=0.04\right)$.

\section{Individual heterozygosity}

Mean individual heterozygosity was $0.79( \pm 0.17)$ and did not correlate with individual nematode infection intensities $(\mathrm{r}=0.05, \mathrm{p}=0.8, \mathrm{n}=24$, Figure 3$)$. 


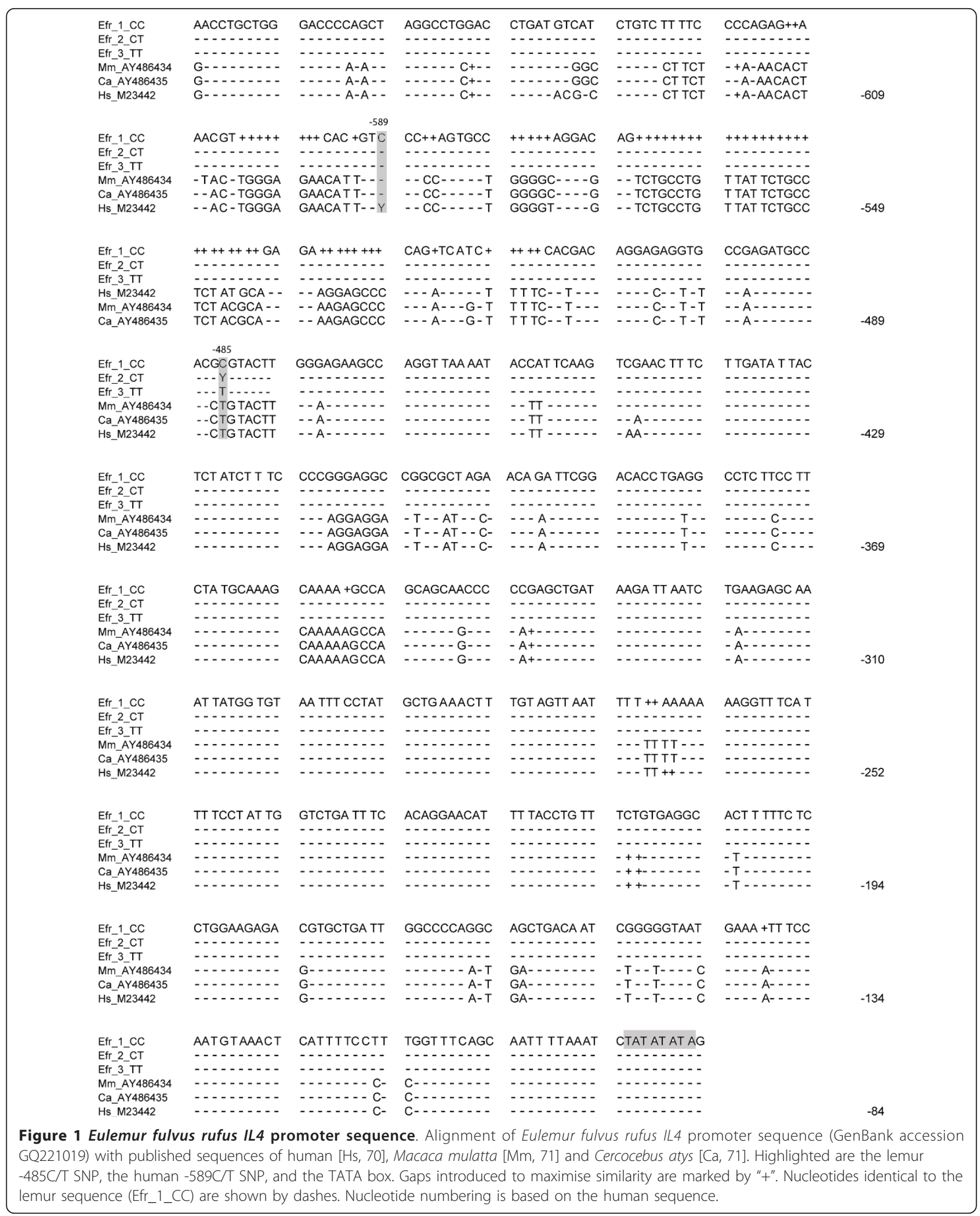




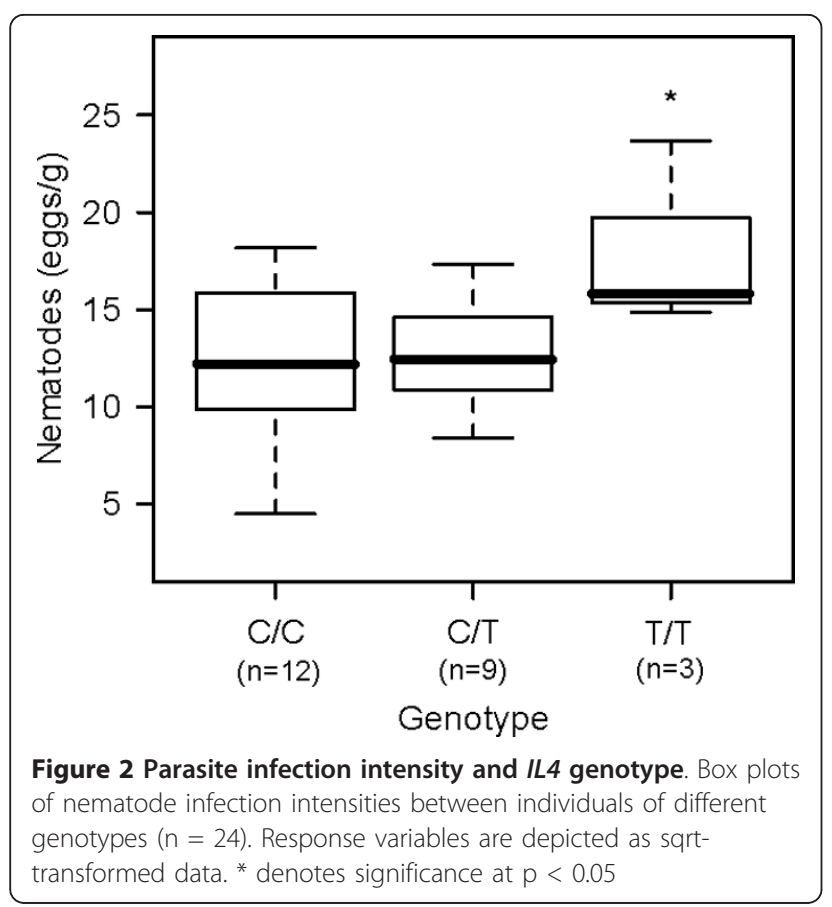

Fitness consequences of different IL4 genotypes

Observed reproductive success (ORS) of males of different genotypes ranged from 0 to $100 \%$ and differed significantly from expected values (Expected reproductive success ERS). Individuals with the genotype $T / T$ sired significantly more offspring than expected $\left(\mathrm{ORS}_{\mathrm{TT}}=\right.$ $13 \% ; \mathrm{ERS}_{\mathrm{TT}}=7 \% ; \chi^{2}=4.47, \mathrm{p}<0.05, \mathrm{df}=1 ; \mathrm{n}_{\mathrm{T} / \mathrm{T}}=9$; Figure 4), whereas observed paternity success in individuals of genotype $\mathrm{C} / \mathrm{C}\left(\mathrm{n}_{\mathrm{C} / \mathrm{C}}=33\right)$ and $\mathrm{C} / \mathrm{T}\left(\mathrm{n}_{\mathrm{C} / \mathrm{T}}=\right.$ 17) did not deviate from expectations (Figure 4).

\section{Discussion}

In this study, we combined information on individual parasite infection intensities, immune-genetic constitution, and long-term parentage patterns to investigate a potential regulatory and functional role of IL4 SNPs on enteric parasite infections in a wild primate population. We detected a polymorphic site at the IL4 gene promoter region at position -485 bp that was not identical to known and functionally relevant $I L 4$ promoter polymorphisms in humans or other non-human primates

Table 1 General linear mixed effect model of nematode infection intensity

\begin{tabular}{lcccc}
\hline Term & df & $\boldsymbol{\chi}^{\mathbf{2}}$-value & P-value & Effect direction \\
\hline IL4 & $\mathbf{2}$ & $\mathbf{1 4 . 1 4}$ & $<\mathbf{0 . 0 0 1}$ & T/T $>$ C/C, C/T \\
sex & 1 & 0.0091 & 0.924 & No effect \\
season & 2 & $<0.001$ & 0.99 & No effect \\
\hline
\end{tabular}

Significant terms are highlighted in bold. P-values were estimated by comparison with reduced models not containing the term in question (likelihood-ratio test), $\mathrm{n}=24$.

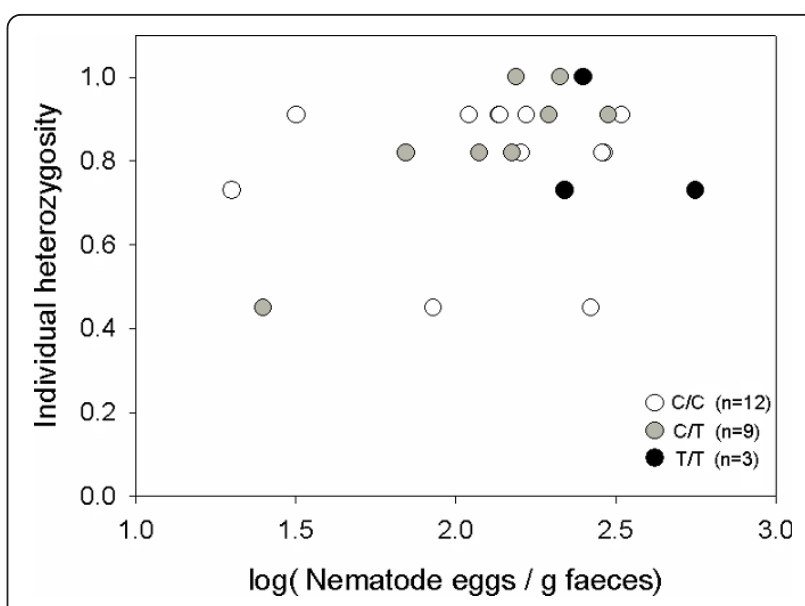

Figure 3 Parasite infection intensity and individual heterozygosity. Nematode infection intensities are not associated with individual heterozygosity $(r=0.05, p=0.8, n=24)$. Genotypes are displayed in different shades.

[29,43-45]. We investigated individual parasite infection intensities with regard to different IL4 genotypes and found evidence for differential association of the three groups of genotypes with nematode infection intensities: animals carrying the rare genotype $(\mathrm{T} / \mathrm{T})$ had higher nematode egg outputs than carriers of the genotype $\mathrm{C} / \mathrm{C}$ and $\mathrm{C} / \mathrm{T}$. However, contrary to our expectations, longterm population analyses indicated a disproportionately higher reproductive success of genotype $\mathrm{T} / \mathrm{T}$ individuals.

\section{IL4 promoter polymorphisms and parasite infections}

In general, promoter SNP-modulated gene transcription can lead to differential activity of a gene and is frequently based upon altered transcription factor binding properties at the site of the mutation [46]. Studies in

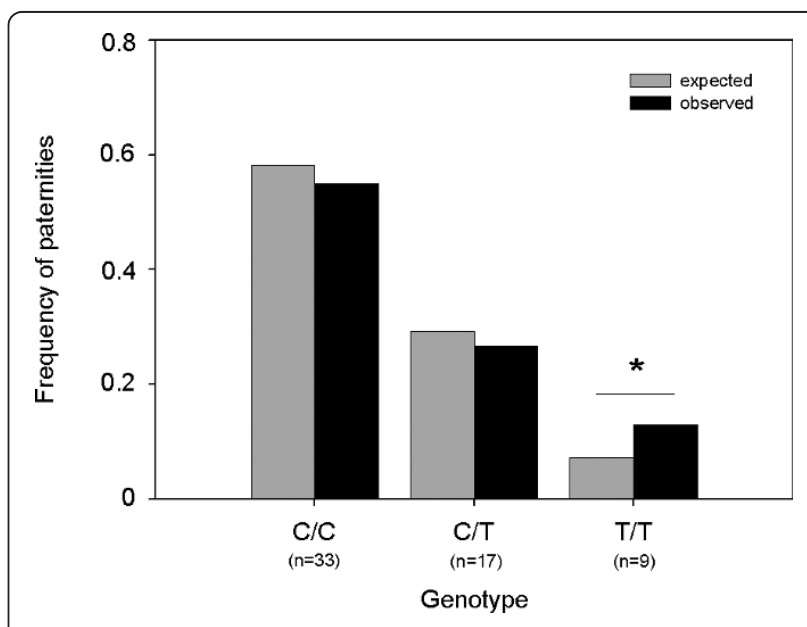

Figure 4 Distribution of paternity share between different IL4 genotypes. Observed frequencies of paternities differed significantly from expected patterns in animals of genotype T/T $(n=59)$. 
vivo and in vitro on a well-known human $\mathrm{C} / \mathrm{T}$ polymorphism $(-589 \mathrm{CT})$ showed that individual genotypes bearing the binding site of transcription factor nuclear factor of activated T-cells (NFAT) [47]) had altered transcription rates of IL4 mRNA resulting in differential IL-4 production $[23,24,27,46,48]$. Experimental evidence for altered transcription rates cannot be provided here. Yet, we suggest that the $-485 \mathrm{C} / \mathrm{T}$ SNP detected in redfronted lemurs affects $I L 4$ gene transcription in a similar way: decreased IL4 mRNA and thus decreased IL-4 protein levels in $\mathrm{T} / \mathrm{T}$ individuals could thus contribute to higher nematode infection intensities as IL-4 is known to play an important role in enteropathic expulsion of nematode worms and increases mucosal permeability after infections [31-34]. Alternatively, the observed association of IL4 polymorphism and infection intensities could be due to linkage disequilibrium of IL4 with other genes such as IL13 and IL5, which in humans are located just $12.5 \mathrm{~kb}$ and $132 \mathrm{~kb}$ upstream of IL4 and are also key $\mathrm{T}_{\mathrm{H}} 2$ cytokines [31].

\section{Individual heterozygosity and parasite infections}

Mean individual heterozygosity in the study population was 0.79 , which suggests that the population was not subject to inbreeding. In line with results from other studies $[15,49]$ and our expectations, the present findings did not confirm a relationship between individual heterozygosity and parasite infection intensity, suggesting that enteric parasite infection in lemurs is associated with one specific genotype of a candidate-gene rather than with heterozygosity per se. The power of this result is certainly constrained by the ability to estimate overall heterozygosity by use of a limited number of microsatellite markers [50,51]. However, the usage of 11 microsatellite markers is comparable to most previous studies in vertebrates $[13,15,49,52]$.

\section{Functional significance of the IL4 polymorphism}

Significant parasite resistance is generally thought to be beneficial in terms of individual fitness [10,53]. We expected individuals with the more common genotypes $(\mathrm{C} / \mathrm{C}$ and $\mathrm{C} / \mathrm{T})$, characterized by low parasite infection levels, to be superior to $\mathrm{T} / \mathrm{T}$ individuals, which had highest infection levels. However, long-term paternity analyses indicated a disproportionally higher reproductive success of these $\mathrm{T} / \mathrm{T}$ males, although the genotype was only found in $11 \%$ individuals of the total study population. This indication of a negative frequencydependent association (low frequency - high reproductive success) is contradictory to other studies conducted on birds [54,55] and fish [56].

A potential explanation may be found in the counterbalancing function of IL-4. A regulatory polymorphism in the IL4 promoter can influence the activity of the cytokine and thus the balance of the $T_{H} 1 / T_{H} 2$ ratio. Such a balancing function results either in an increased $\mathrm{T}_{\mathrm{H}} 1$ response (low IL-4 level), potentially advantageous when individuals are confronted with intracellular pathogens such as viruses or phagocytised bacteria, or an intensified $\mathrm{T}_{\mathrm{H}} 2$ response (high IL-4 level), required when individuals are affected by extra-cellular parasites such as nematode worms [48]. This suggests that the IL4 promoter polymorphism may be subject to balancing selection. Imbalanced $\mathrm{T}_{\mathrm{H}} 1 / \mathrm{T}_{\mathrm{H}} 2$ ratios are known to be responsible for the lepromatous form of leprosy and influence susceptibility to allergy in "parasite-free" industrialized areas in human $[57,58]$. With regard to our study population, it is likely that an IL4-regulated and intensified $\mathrm{T}_{\mathrm{H}} 1$ response targeting microparasites (not measured in this study) could provide an explanation for the disproportionately higher reproductive success of these animals. Yet, although this scenario is a plausible explanation for the significantly higher longterm reproductive success of $\mathrm{T} / \mathrm{T}$ individuals, the IL4 gene is certainly only one of many factors affecting variance in male reproductive success in a wild lemur population [40]. Additionally, increased levels of nematode infection might not be a crucial aspect in selection processes of this particular population. Analyses on determinants of parasite infection in red-fronted lemurs published elsewhere [41] show, for example, that the intensity and species richness of nematode infections has no effect on social rank or mating success. In addition, most prominent nematode species found in this study are not considered as highly pathogenic [42] when compared to tissue migrating nematodes that may also contribute to anaemia and secondary bacterial disease [59].

\section{Limitations of the study}

This is the first study exploring the significance of IL4 polymorphisms simultaneously in several groups of a wild primate species, which involves an unusually large logistic effort. There are two major caveats in this study, which ask for a cautious interpretation of our results. First, studying natural populations of primates is often associated with the drawback of working with small sample sizes - in particular when compared to laboratory-based studies with murine models - and in our study, the number of individuals per individual genotype, in particular for the most interesting genotype, was very low (year 2007: $\mathrm{n}_{\mathrm{T} / \mathrm{T}}=3$ ). To minimise bias, we used conservative statistical methods that accounted for non-independent data and unbalanced designs. Second, this is a genetic association study and lacks in-vitro and in-vivo evidence of $T_{H} 1 / T_{H} 2$-driven responses influenced by promoter polymorphisms. In particular, this leads to a speculation that the $\mathrm{T} / \mathrm{T}$ genotype has 
diminished expression of a $\mathrm{T}_{\mathrm{H}} 2$ immune response, contributing to the higher nematode egg excretion levels observed. Recent functional studies (particularly in mice) have established the link between $\mathrm{T}_{\mathrm{H}} 2$ levels and parasite infection intensities in detail $[18,20]$.

These two caveats hamper firm conclusions for the time being. While our results suggest interesting patterning of an IL4 polymorphism and its effect on intestinal parasite infection in wild primates that can be explained biologically, these caveats will need to be addressed in future studies to improve the data basis and our mechanistic understanding of the observed pattern.

\section{Conclusions}

We detected a novel $\mathrm{C} / \mathrm{T}$ polymorphism at position $-485 \mathrm{bp}$ in the promoter region of the IL4 gene in a wild primate population. The association of this polymorphism and inter-individual variability in nematode infection encountered in this lemur population indicated that carriers of a rare genotype had higher nematode infection intensities than carriers of the more common genotypes. However, against our expectations, long-term paternity analyses indicated above-average reproductive success of the former.

Due to low frequencies of the particular IL4 genotype in our study population final conclusions on the functional role of IL4 polymorphism cannot be drawn yet. Still, the methodological approach used in this study may contribute to a better understanding of the actual components of the immune response that mediate protection against helminth parasites and is recommended for further studies. If similar patterns are found in other natural study systems, the analyses of IL4 promoter SNPs could provide an efficient scoring system for susceptibility to helminth infections.

\section{Methods}

\section{Study site and sample collection}

Data were collected at the study site of the German Primate Center (DPZ) in Kirindy Forest, western Madagascar. Detailed description of the study site can be found in Sorg et al [60]. Between 1996 and 2007, adult redfronted lemurs of the study population belonging to four social groups (groups A, B, F, J) living within a 60 ha study area have been regularly captured and marked individually with unique nylon or radio collars (in total: 48 males, 16 females). From these animals, small tissue samples were routinely taken and stored in 70-90\% ethanol for DNA extraction [40]. During a 3-month study period between April and July 2007, a total of 299 faecal samples were collected weekly from each individual of the current population (13 males, 11 females) for parasitological analyses. Individually assigned samples were taken immediately after defecation, stored in labelled vials containing $10 \%$ buffered formalin. All samples were transported to DPZ laboratories, Germany, for analyses. Ethical approval for this study was not necessary because our research was not experimental. Study animals were not subjected to experimental manipulations to obtain any of the data presented in this paper. All field work was carried out following the guidelines of the American Society of Mammalogists. The capture of study animals, which was used to obtain tissue samples, was authorized by the Malagasy Ministère de l'Environnement et des Eaux et Forêts.

\section{Genetic analyses}

\section{IL4 promoter sequencing}

DNA was isolated from tissue samples of all 64 individuals using QIAamp ${ }^{\circledR}$ tissue kits (Qiagen). A fragment of the $I L 4$ gene promoter region was amplified using primers: forward 5'-CATACGAACCTGCTGGGAC-3' and reverse 5'-CAATCAGCACGTCTCTTCCA-3'. Hot start PCR was carried out in a total volume of $30 \mu \mathrm{l}$ with $10 \mathrm{pmol}$ of each primer, $166 \mu \mathrm{M}$ dNTPs, and $2 \mathrm{U}$ Taq DNA polymerase. Amplification was performed according to the following protocol: $5 \mathrm{~min}$ at $92^{\circ} \mathrm{C}, 45$ cycles of $92^{\circ} \mathrm{C}$ for $1 \mathrm{~min}, 58^{\circ} \mathrm{C}$ for $1 \mathrm{~min}$ and $1 \mathrm{~min}$ at $72^{\circ} \mathrm{C}$, and final elongation for $5 \mathrm{~min}$ at $72^{\circ} \mathrm{C}$. PCR products were purified with the Millipore DNA purification kit (Millipore, Schwalbach, Germany) and sequencing was performed in both directions with a BigDye terminator sequencing kit (Applied Biosystems, Darmstadt, Germany) in an ABI $3130 \times 1$ automated capillary sequencer (Applied Biosystems) with same primers as mentioned above. Individual IL4 sequences were aligned and examined for occurrence of SNPs using the biological sequence alignment editor BioEdit 7.0.9 [61]. The newly discovered SNP at position -485 bp upstream the transcription start has been submitted for publication in dbSSNP data base [ss142460308]. The IL4 promoter sequence is stored in the DDBJ/EMBL/Genbank database, accession number GQ221019.

\section{Individual heterozygosity}

Controlling for a potential heterozygosity effect, we analysed the effect of multi-locus marker heterozygosity $(\mathrm{MLH})$ on parasite infection $[52,62]$. Animals from the 2007 population ( $\mathrm{n}=24$, see above) were typed at eleven highly variable microsatellite markers [see [40,63]] and MLH was determined as the proportion of typed loci for which an individual was heterozygous [64]. Allele frequency analyses conducted in CERVUS 2.0 confirmed that none of the markers deviated significantly from Hardy-Weinberg-equilibrium.

\section{Reproductive success}

Exploring a functional role of different IL4 genotypes on male reproductive success, long-term reproductive 
success of all males abundant in all four social groups of the study population from 1996 to $2007(\mathrm{n}=48)$ was assessed via parentage analyses. During this time period, 59 offspring of which fathers could be identified genetically were born in the study population. Detailed methods on microsatellite-based paternity analyses as well as paternities are published elsewhere [40]. As both dominant and subordinate males mate multiply with females and there is only very little mating skew within a social group [39], we predicted expected male reproductive success (ERS) based on the distribution of males with respective genotypes $(\mathrm{C} / \mathrm{C}, \mathrm{C} / \mathrm{T}, \mathrm{T} / \mathrm{T})$ per social group, year, and the number of offspring born to the group in the respective year. Based on the result of paternity analyses, we then calculated observed male reproductive success (ORS) per genotype and year.

\section{Parasitological analyses}

Faecal parasites samples were processed using a modified form of the formalin-ethyl-acetate sedimentation technique as described by Ash and Orihel [65], and detailed methods can be found elsewhere [42]. Wet mounts were prepared using $20 \mathrm{mg}$ faecal sediment, analyzing individual samples for intestinal helminth parasites (nematodes, cestodes, trematodes). Larvae and adult stages found in faecal samples were used for identification of morpho-species. In cases were adult worms were available determination to species level was possible. Due to very low numbers of trematode and cestode parasitic stages (see Ref. [42] for details), we focussed our analyses of helminth parasites on nematodes. Results on nematode egg morpho-types were extrapolated to $1 \mathrm{~g}$ faecal sediment (x50). We used parasite infection intensity (number of eggs) as a measure of parasite infection levels. Due to parasite-specific variation in egg shedding, there has been some discussion about the reasonable use of faecal egg counts as a measure of infection intensity $[66,67]$. We accounted for natural occurring variation in parasitic excretions by using monthly medians of faecal egg/cyst counts per individual and pooling the data for all nematode infections to generate the response variables for statistical analyses.

\section{Statistical analyses}

We used monthly means of faecal egg counts per individual as a measure for natural occurring variations in parasitic excretions [66,67]. We modelled differences between individuals of different genotypes using a linear mixed model approach (lmer in R [68]). As both response variables showed high degrees of overdispersion (see Ref. [41] for details), which could not be improved by applying a GLMM (link = log) with quasi-error structure as advised for use of parasitological data [69], we used square-root transformed data on individual means (GLMM, link = identity). After transformation distributions of response variables were no longer different from the normal distribution. Homogeneity of variances was checked using residual plots. Residuals of all models were constant and normally distributed as checked by Q-Q plots. Non-independence of repeated measurements per individual as well as potential group-specific variation (e. g. due to behavioural differences or habitat use)was accounted for by incorporating individual nested in group (four levels: social group A, B, F, J) [69]. As we know from earlier analyses (published elsewhere, see Ref [41]) that season and sex can have a significant effect on the intensity of parasite infection, we included both factors as fixed effect covariates in the model. Full model structure was: Response $=$ nematode infection intensity; Fixed effect factor $=$ genotype; Fixed effects covariate $=$ sex, season (pre-, mating, post-season as defined in Ref. [41]); Random effects = individual, group. Model simplification was conducted by step-wise removal of non-significant parameters. Nested models with different fixed effects were compared using likelihood-ratio tests with ML estimation [70], which was also used to confirm lack of contribution of eliminated variables. P-values for mixed models were estimated using Markov Chain Monte Carlo (MCMC) simulations [71].

Relationships of individual heterozygosity (MLH) and nematode infection intensities (log-transformed) were assessed using Spearman rank correlation analyses. Observed and expected frequencies of paternities per offspring per male were compared between genotypes with $\chi^{2}$ test statistics. All statistical analyses were performed with software R (Version 2.8.1 [72]) and the significance level was set at 0.05 .

\section{Acknowledgements}

We thank the Malagasy Ministère de l' Environment et des Eaux et Forêts, the Department Biologie Animale de l'Université d'Antanarivo, and the Centre National de Formation d'Etudes et de Recherche en Environnement et Foresterie de Morondava for authorizing and supporting research in Kirindy, Madagascar. Collection of faecal samples was greatly supported by our field assistant Remi Ampataka. Our thanks also go to Christina Oberdieck for valuable support in the laboratory. Yann Clough, Elise Huchard and three anonymous reviewers provided helpful comments on an earlier version of the paper. DC was supported by a Villigst e.V. graduate scholarship with additional funding from the Unit of Behavioral Ecology and Sociobiology and Primate Genetics Laboratory, DPZ.

\section{Author details}

'Behavioral Ecology and Sociobiology Unit, German Primate Center, Kellnerweg 4, 37077 Göttingen, Germany. ${ }^{2}$ Dept. of Anthropology / Sociobiology, University of Göttingen, Kellnerweg 6, 37077 Göttingen, Germany. ${ }^{3}$ Primate Genetics Laboratory, German Primate Center, Kellnerweg 4, 37077 Göttingen, Germany.

\section{Authors' contributions}

DC, PMK and LW designed the study. DC took the leading role in writing the manuscript, PMK and LW contributed to the manuscript. All authors read and approved the final version of the manuscript. 


\section{Competing interests}

The authors declare that they have no competing interests.

Received: 25 October 2010 Accepted: 18 April 2011

Published: 18 April 2011

\section{References}

1. Gillespie TR, Chapman CA, Greiner EC: Effects of logging on gastrointestinal parasite infections and infection risk in African primates. J Appl Ecol 2005, 42:699-707.

2. Stephenson LS, Latham MC, Ottesen EA: Malnutrition and parasitic helminth infections. Parasitology 2000, 121:S23-S38.

3. Chan MS, Medley GF, Jamison D, Bundy DA: The evaluation of potential global morbidity attributable to intestinal nematode infections. Parasitology 1994, 109:373.

4. Penn DJ, Damjanovich K, Potts WK: MHC heterozygosity confers a selective advantage against multiple-strain infections. Proc Natl Acad Sci 2002, 99:11260-11264.

5. Schad J, Ganzhorn JU, Sommer S: Parasite burden and constitution of major histocompatibility complex in the malagasy mouse lemur, Microcebus murinus. Evolution 2005, 59:439-450.

6. Schwensow N, Eberle M, Sommer S: Compatibility counts: MHC-associated mate choice in a wild promiscuous primate. Proc R Soc Lond B 2008, 275:555-564.

7. Harf R, Sommer S: Association between major histocompatibility complex class II DRB alleles and parasite load in the hairy-footed gerbil, Gerbillurus paeba, in the southern Kalahari. Mol Ecol 2005, 14:85-91.

8. Milinski M: The major histocompatibility complex, sexual selection, and mate choice. Annu Rev Ecol Syst 2006, 37:159-186.

9. Huchard E, Knapp LA, Wang J, Raymond M, Cowlishaw G: MHC, mate choice and heterozygote advantage in a wild social primate. Mol Ecol 2010, 19:2545-2561.

10. Hamilton WD, Zuk M: Heritable true fitness and bright birds: a role for parasites? Science 1982, 218:384-387.

11. Wedekind C, Seebeck T, Bettens F, Paepke AJ: MHC-dependent mate preferences in humans. Biol Sci 1995, 260:245-249.

12. Potts WK, Manning CJ, Wakeland EK: Mating patterns in seminatural populations of mice influenced by MHC genotype. Nature 1991 352:619-621.

13. Coltman DW, Pilkington JG, Smith JA, Pemberton JM: Parasite-mediated selection against inbred Soay sheep in a free-living, island population. Evolution 1999, 53:1259-1267.

14. Carrington M, Nelson GW, Martin MP, Kissner T, Vlahov D, Goedert JJ, Kaslow R, Buchbinder S, Hoots K, O'Brien SJ: HLA and HIV-1: heterozygote advantage and $B^{*} 35-\mathrm{CW}^{*} 04$ disadvantage. Science 1999, 283:1748-1752.

15. Côté SD, Stien A, Irvine RJ, Dallas JF, Marshall JF, Halvorsen O, Langvatn R, Albon SD: Resistance to abomasal nematodes and individual genetic variability in reindeer. Mol Ecol 2005, 14:4159-4168.

16. Cassinello J, Gomendio M, Roldan ERS: Relationship between coefficient of inbreeding and parasite burden in endangered gazelles. Conserv Biol 2001, 15:1171-1174.

17. Hill AVS: Aspects of genetic susceptibility to human infectious diseases. Annu Rev Genet 2006, 40:469-486.

18. Hotez PJ, Brindley PJ, Bethony JM, King CH, Pearce EJ, Jacobson J: Helminth infections: the great neglected tropical diseases. J Clin Invest 2008, 118:1311-1321.

19. Fumagalli M, Pozzoli U, Cagliani R, Comi GP, Riva S, Clerici M, Bresolin N, Sironi M: Parasites represent a major selective force for interleukin genes and shape the genetic predisposition to autoimmune conditions. J Exp Med 2009, 206:1395-1408.

20. King IL, Mohrs M: IL-4-producing CD4+ T cells in reactive lymph nodes during helminth infection are T follicular helper cells. J Exp Med 2009, 206:1001-1007.

21. Song Z, Casolaro V, Chen R, Georas SN, Monos D, Ono SJ: Polymorphic nucleotides within the human IL-4 promoter that mediate overexpression of the gene. J Immunol 1996, 156:424-429.

22. Luoni G, Verra F, Arcà B, Sirima BS, Troye-Blomberg M, Coluzzi M, Kwiatkowski D, Modiano D: Antimalarial antibody levels and IL4 polymorphism in the Fulani of West Africa. Genes Immun 2001, 2:411-414.
23. Nakashima H, Miyake K, Inoue Y, Shimizu S, Akahoshi M, Tanaka Y, Otsuka T, Harada M: Association between IL-4 genotype and IL-4 production in the Japanese population. Genes Immun 2002, 3:107-109.

24. Wierenga $E A$, Messer G: Regulation of Interleukin 4 gene transcription. Alterations in atopic disease? Am J Resp Crit Care 2000, 162:S81-85.

25. Verra F, Luoni G, Calissano C, Troye-Blomberg M, Perlmann P, Perlmann H, Arcà B, Sirima BS, Konaté A, Coluzzi M, et al: IL4-589C/T polymorphism and IgE levels in severe malaria. Acta Tropica 2004, 90:205-209.

26. Gyan BA, Goka B, Cvetkovic JT, Kurtzhals JL, Adabayeri V, Perlmann H, Lefvert AK, Akanmori BD, Troye-Blomberg M: Allelic polymorphisms in the repeat and promoter regions of the interleukin-4 gene and malaria severity in Ghanaian children. Clin Exp Immunol 2004, 138:145-150.

27. Rosenwasser Lanny J, Borish L: Genetics of Atopy and Asthma: The rationale behind promoter-based candidate gene studies (IL-4 and IL10). Am J Resp Crit Care 1997, 156:S152-155.

28. Basehore MJ, Howard TD, Lange LA, Moore WC, Hawkins GA, Marshik PL, Harkins MS, Meyers DA, Bleecker ER: A comprehensive evaluation of IL4 variants in ethnically diverse populations: association of total serum lgE levels and asthma in white subjects. J Allergy Clin Immun 2004, 114:80-87.

29. Kabesch M, Tzotcheva I, Carr D, Höfler C, Weiland SK, Fritzsch C, von Mutius E, Martinez FD: A complete screening of the IL4 gene: Novel polymorphisms and their association with asthma and IgE in childhood. J Allergy Clin Immun 2003, 112:893-898.

30. Paffen E, Medina P, de Visser MCH, van Wijngaarden A, Zorio E, Estelles A, Rosendaal FR, Espana F, Bertina RM, Doggen CJM: The -589 C > T polymorphism in the interleukin-4 gene (IL-4) is associated with a reduced risk of myocardial infarction in young individuals. J Thromb Haemost 2008, 6:1633-1638.

31. Anthony RM, Rutitzky LI, Urban JF, Stadecker MJ, Gause WC: Protective immune mechanisms in helminth infection. Nat Rev Immunol 2007, 7:975-987.

32. Lawrence CE, Paterson JCM, Higgins LM, MacDonald TT, Kennedy MW, Garside P: IL-4-regulated enteropathy in an intestinal nematode infection. Eur J Immunol 1998, 28:2672-2684.

33. Finkelman FD, Shea-Donohue T, Morris SC, Gildea L, Strait R, Madden KB, Schopf L, Urban JF: Interleukin-4- and interleukin-13-mediated host protection against intestinal nematode parasites. Immunol Rev 2004 201:139-155

34. Zhao A, McDermott J, Urban JF Jr, Gause W, Madden KB, Yeung KA, Morris SC, Finkelman FD, Shea-Donohue T: Dependence of IL-4, IL-13, and nematode-induced alterations in murine small intestinal smooth muscle contractility on Stat6 and enteric nerves. I Immunol 2003, 171:948-954.

35. Kappeler PM: Causes and consequences of unusual sex ratios among lemurs. In Primate males: causes and consequences of variation in group composition. Edited by: Kappeler PM. Cambridge: Cambridge University Press; 2000:158-170.

36. Ostner J, Kappeler PM: Male life history and the unusual adult sex ratios of redfronted lemur, Eulemur fulvus rufus, groups. Anim Behav 2004, 67:249-259.

37. Ostner J, Kappeler PM: Central males instead of multiple pairs in redfronted lemurs, Eulemur fulvus rufus (Primates, Lemuridae)? Anim Behav 1999, 58:1069-1078.

38. Overdorff DJ: Are Eulemur species pair-bonded? Social organization and mating strategies in Eulemur fulvus rufus from 1988-1995 in southeast Madagascar. Am J Phys Anthropol 1998, 105:153-166.

39. Port M, Kappeler PM: The utility of reproductive skew models in the study of male primates, a critical evaluation. Evol Anthropol 2010, 19:46-56.

40. Kappeler PM, Port M: Mutual tolerance or reproductive competition? Patterns of reproductive skew among male redfronted lemurs (Eulemur fulvus rufus). Behav Ecol Sociobiol 2008, 62:1477-1488.

41. Clough D, Heistermann M, Kappeler PM: Host-intrinsic determinants and potential consequences of parasite infection in free-ranging red-fronted lemurs (Eulemur fulvus rufus). Am J Phys Anthropol 2010, 142:441-452.

42. Clough D: Gastro-intestinal parasites of red-fronted lemurs in Kirindy Forest, Western Madagascar. J Parasitol 2010, 96:245-251.

43. Rosenwasser $\amalg$, Klemm DJ, Dresback JK, Inamura H, Mascali JJ, Klinnert M, Borish L: Promoter polymorphisms in the chromosome- 5 gene-cluster in asthma and atopy. Clin Exp Allergy 1995, 25:74-78. 
44. Takabayashi A, Ihara K, Sasaki Y, Kusuhara K, Nishima S, Hara T: Novel polymorphism in the $5^{\prime}$-untranslated region of the interleukin- 4 gene. $J$ Hum Genet 1999, 44:352.

45. Hackstein H, Hecker M, Kruse S, Bohnert A, Ober C, Deichmann KA, Bein G: A novel polymorphism in the 5 'promoter region of the human interleukin- 4 receptor a-chain gene is associated with decreased soluble interleukin-4 receptor protein levels. Immunogenetics 2001, 53:264-269.

46. Li-Weber M, Krammer PH: Regulation of IL4 gene expression by T cells and therapeutic perspectives. Nat Rev Immunol 2003, 3:534-543.

47. Macian F: NFAT proteins: key regulators of T-cell development and function. Nat Rev Immunol 2005, 5:472-484.

48. Rockman MV, Hahn MW, Soranzo N, Goldstein DB, Wray GA: Positive selection on a human-specific transcription factor binding site regulating IL4 expression. Curr Biol 2003, 13:2118-2123.

49. Ortego JIN, Cordero PJ, Aparicio JM, Calabuig G: No relationship between individual genetic diversity and prevalence of avian malaria in a migratory kestrel. Mol Ecol 2007, 16:4858-4866.

50. DeWoody YD, DeWoody JA: On the estimation of genome-wide heterozygosity using molecular markers. J Hered 2005, 96:85-88.

51. Slate J, David P, Dodds KG, Veenvliet BA, Glass BC, Broad TE, McEwan JC: Understanding the relationship between the inbreeding coefficient and multilocus heterozygosity: theoretical expectations and empirical data. Heredity 2004, 93:255-265.

52. Schwensow N, Fietz J, Dausmann KH, Sommer S: Neutral versus adaptive genetic variation in parasite resistance: importance of major histocompatibility complex supertypes in a free-ranging primate. Heredity 2007, 99:265-277.

53. Clayton DH: The influence of parasites on host sexual selection. Parasitol Today 1991, 7:329-334.

54. Dobson AP, Hudson PJ: Regulation and stability of a free-living hostparasite system: Trichostrongylus tenuis in red grouse. I. Monitoring and parasite reduction experiments. J Anim Ecol 1992, 61:487-498.

55. Møller AP: Effects of parasitism by a hematophagous mite on reproduction in the Barn Swallow. Ecology 1990, 71:2345-2357.

56. Milinski M, Bakker TCM: Female sticklebacks use male coloration in mate choice and hence avoid parasitized males. Nature 1990, 344:330-333.

57. Yazdanbakhsh M, Kremsner PG, van Ree R: Allergy, parasites, and the hygiene hypothesis. Science 2002, 296:490-494.

58. Modlin RL: Th1-Th2 Paradigm: Insights from Leprosy. J Investig Dermatol 1994, 102:828-832.

59. Gilman RH: Hookworm disease: host-pathogen biology. Ref Infect Dis 1982, 4:824-829.

60. Sorg J-P, Ganzhorn JU, Kappler PM: Forestry and research in the Kirindy / Centre de Formation Professionelle Forestière. In The Natural History of Madagascar. Edited by: Goodman SM, Benstead JP. Chicago: The University of Chicago Press; 2004:1512-1519.

61. Hall TA: BioEdit: Biological sequence alignment editor for Windows 95/ 98/NT/2K/XP. 1999.

62. Allendorf FW, Leary RF: Heterozygosity and fitness in natural populations of animals. In Conservation Biology. Edited by: Soule ME. Sunderland, MA, Sinauer Associates; 1986:57-76.

63. Wimmer B, Kappeler PM: The effects of sexual selection and life history on the genetic structure of redfronted lemur, Eulemur fulvus rufus, groups. Anim Behav 2002, 64:557-568.

64. Slate J, Kruuk LE, Marshall TC, Pemberton JM, Clutton-Brock TH: Inbreeding depression influences lifetime breeding success in a wild population of red deer (Cervus elaphus). Proc R Soc Lond B 2000, 267:1657-1662.

65. Ash LR, Orihel TC: Parasites: A guide to laboratory procedures and identification. Chicago, Illinois: American Society of Clinical Pathologists; 1991.

66. Anderson RM, Schad GA: Hookworm burdens and faecal egg counts: an analysis of the biological basis of variation. T Roy Soc Trop Med 1985, 79:812-825.

67. Gillespie TR: Noninvasive assessment of gastrointestinal parasite infections in free-ranging primates. Int J Primatol 2006, 27:1129-1143.

68. Bates D, Maechler M, Dai B: Ime4: Linear Mixed-Effects Models using S4 classes. R package version 0.999375-28; 2008.

69. Paterson S, Lello J: Mixed models: getting the best use of parasitological data. Trends Parasitol 2003, 19:370-375.

70. Zuur AF, leno EN, Walker NJ, Saveliev AA, Smith GM: Mixed Effects Models and Extensions in Ecology With R. Springer; 2009.
71. Baayen RH, Davidson DJ, Bates DM: Mixed-effects modeling with crossed random effects for subjects and items. J Mem Lang 2008, 59:390-412.

72. R Development Core Team: R: A language and environment for statistical computing. Vienna, Austria: R Foundation for Statistical Computing; 2008.

doi:10.1186/1742-9994-8-9

Cite this article as: Clough et al: Genetic regulation of parasite infection: empirical evidence of the functional significance of an IL4 gene SNP on nematode infections in wild primates. Frontiers in Zoology 2011 8:9.

\section{Submit your next manuscript to BioMed Central and take full advantage of:}

- Convenient online submission

- Thorough peer review

- No space constraints or color figure charges

- Immediate publication on acceptance

- Inclusion in PubMed, CAS, Scopus and Google Scholar

- Research which is freely available for redistribution

Submit your manuscript at www.biomedcentral.com/submit
Biomed Central 